\title{
Pharmacokinetic Study of Viral Vectors for Gene Therapy: Progress and Challenges
}

\author{
Xianxing $\mathrm{Xu}^{1}$, Jingwen Yang $^{2}$ and Yuanguo Cheng ${ }^{1}$ \\ ${ }^{1}$ Department of Pharmacology, State Key Laboratory of Pathogen and Biosecurity, \\ Beijing Institute of Microbiology and Epidemiology, \\ ${ }^{2}$ Department of neurobiology, Beijing Institute of Basic Medical Science, \\ PR China
}

\section{Introduction}

Gene therapy may be described as the use of genes as medicines to treat disease, or, more precisely, as the delivery of nucleic acids by means of vectors to patients for some therapeutic purpose (Thanou, M. et al., 2007). The major goal of gene therapy is to introduce a functional gene into a target cell and restore protein production that is absent or deficient due to a genetic disorder (Neeltje, A. et al., 2003). This approach is a potentially powerful method for the treatment of diseases for which classical pharmacotherapy is unavailable or not easily applicable.

Gene therapy is a therapeutic modality with enormous promise, which is also considered to have failed to deliver much of therapeutic significance in spite of all the apparent clinical interest. Clinical trial activity in gene therapy began in 1989, peaked in 1999, and is now currently declining (Thanou, M. et al., 2007). This decline was marked by some clinical trial problems, including a death from toxic liver shock during an adenovirus-based clinical trial in 1999 (Marshall, E., 2000), the anomalous appearance of a transgene in the gonads during adeno-associated virus-based preclinical trials in 2001 (Arruda, V. R. et al., 2001), signs of hypertension in lipofection clinical trials in 2005 (Pro-1) (MacLachlan, I. et al., 1999), and the development of leukemia in retrovirus-based clinical trials for ex vivo treatment of X-linked severe combined immunedeficiency (X-linked SCID) (Cavazzana-Calvo, M. et al., 2004; Gaspar, H. B., \& Thrasher, A. J., 2005).

Lessons from those frustrated results suggest that more basic research is required in gene therapy study, including mechanism of diseases and features of viral vectors. In order to modify a specific cell type or tissue, the therapeutic gene must be efficiently delivered to the cell, so that it will express at the appropriate level for a sufficient duration. Thus, identifying the ideal means of carriage for viral gene therapy is the key rate-limiting step in the development of most promising gene therapy strategies. In spite of long-term and extensive efforts to develop in vivo gene delivery systems, little achievements have been reported, especially as far as clinical applications are concerned. Apparently, the development of gene delivery systems will be one of the most critical issues for the success of in vivo gene therapy.

Over the years, two broad approaches have been used to deliver therapeutic genes to cells, viral vectors and non-viral vectors. These two kinds of vectors are different as regard to 
efficiency, ease of production and safety. Preclinical and current clinical trial data suggest that non-viral vector systems are much less affected by immunogenicity, toxicity, and oncogenicity. However, the lack of delivery efficacy and short-term expression in in vivo also pose their greatest drawback.

By contrast, viral-based vectors are feasible for modification and long-term gene expression, meanwhile, they are characterized by their infectivity and satisfactory targeting, all of which make them even more attractive as gene delivery systems. Nowadays, many viral vectors have been developed and frequently used in the present gene therapy studies, such as Adenovirus, Adeno-associated virus, retroviruses, herpes simplex virus type 1 and vaccinia virus. The real success has been reported with a serotype 5 adenovirus vector delivering the p53 tumor suppressor gene (Gendicine, the World's first commercial gene therapy product, licensed for use in China) (Pearson S. et al., 2004). Viral vectors have also been applied in the treatment of monogenic diseases. In 2000, the World's first curative gene therapy trial was reported after bone marrow cells were isolated from patients with X-linked SCID (Cavazzana-Calvo, M. et al, 2000). In a word, gene therapy with viral vectors has been proven effective in a variety of model systems.

However, studies have also shown that even if some common characteristics exist, an important variability is introduced by the administration route, the promoter and other key components of the construct (targeting modifications, etc) (Dani, S.U., 1999). The variability results in a variety of challenges, including circumvention of immune responses against viral vectors and difficulty in transferring the genes to a sufficient number of cells to change the phenotype, and in controlling the expression of the gene (Worgall, S. \& Crystal, R.G., 2007). Thus, it is currently admitted that pharmacokinetic studies should be carried out prior to any clinical trial for a promising viral gene therapy. Additionally, preexisting knowledge about the viral vectors, including the viral vector titration standardization issues, specific formulation and purification process, also prompts for dedicated pharmacokinetic studies.

Therefore, this chapter reviews the general strategies of the pharmacokinetic studies in viral gene therapy, provides an overview of the pharmacokinetic characteristics of viral vectors and the methods used in pharmacokinetic analysis of viral gene therapy, details the challenges and discusses the strategies being used to improve the analytical modality in viral gene therapy.

\section{Pharmacokinetic characteristics of viral vectors}

Viral vectors currently available for gene therapy can roughly be categorized into integrating and non-integrating vectors. Vectors based on adeno-associated virus and retroviruses (including lentivirus and foamy virus) are classified as integrating vectors as they have the ability to integrate their viral genome into the chromosomal DNA of the host cells, which will possibly achieve lifelong gene expression. Vectors based on adenovirus (Ad), modified vaccinia virus of Ankara (MVA) and herpes simplex virus type 1 (HSV-1) represent the non-integrating vectors (Pfeifer, A. \& Verma, I.M., 2001). These vectors deliver their genomes into the nucleus of the target cells, where they remain episomal. The different behavior between these two kinds of viruses will frequently determine their difference in the availability at the target cells and also the undesirable sites following in vivo administration.

Accordingly, principles of pharmacokinetic study are equally applicable to conventional small-molecule drugs and biotech drugs (Meibohm, B., 2006), including viral vectors. 
However, viral vectors often exhibit unique pharmacokinetic properties that are different from others.

As described previously, replication-deficient viral vectors remain in vivo for a temporal period due to rapidly elimination through degradation as well as by the clearance (Senoo, M., et al, 2000; Hackett, N.R., et al, 2000). Usually, the elimination of viral vectors within tissues or within the blood compartment results from the action of both endonucleases and exonucleases (Goncalves, MA. et al., 2002). Hence, viral nucleic acids must be extracted and detected as soon as possible when performing a pharmacokinetic study with PCR method in case of rapid degradation. However, the suitability or yield of nucleic acid from extraction procedures can vary depending on the nucleic acid and the biological material (Kok, T. et al., 2000). Great differences were found on the recoveries of viral DNA between tissues and blood as shown in Table 1, most experiments produced recovery of greater than $50 \%$, while some were relative low but stable. Interestingly, the lowest recovery was found in blood (Lovatt, A., 2002). Therefore, efficient extraction of target nucleic acid should be evaluated for the particular target and biological material to be used.

\begin{tabular}{cc}
\hline Animal tissue & Recovery $(\%)$ \\
\hline Brain & $60-90$ \\
Kidney & $70-95$ \\
Spleen & $68-80$ \\
Lung & $50-75$ \\
Gonads & $60-90$ \\
Muscle & $10-40$ \\
Blood & $10-20$ \\
Heart & $70-100$ \\
Lymph node & $30-90$ \\
Liver & $65-100$ \\
\hline
\end{tabular}

Table 1. Recovery of 10 100 copies of viral nucleic acid target per 100 microgram of animal tissue extracted with the Qiagen DNA mini kit (tissue and blood protocol)Additionally, it is very important to determine the optimal blood compartment for quantitative measurement of virus in peripheral blood specimens. Perlman, J. et al. compared the use of whole blood (WB), plasma, and peripheral blood mononuclear cells (PBMC) for the detection of adenovirus in peripheral blood specimens from a pediatric HSCT recipient population, and higher viral loads were in WB and plasma than in PBMC (Perlman, J. et al., 2007).

In viral gene therapy, gene expression and duration is an important criterion and controlled by the choice of promoter, CpG content, topological form of DNA etc. Although viral vectors are structurally similar to the wild-type progenitor virus, they generally lack some or all of the viral genes, so that their ability to replicate is frequently impeded or obliterated (Worgall, S. \& Crystal, R.G., 2007). Hence, the lack of sustained transgene expression may be another important characteristic of viral vectors, and must be taken into account when setting up treatment regiments and investigating their pharmacokinetics. What's more, controlling the gene expression is a challenge that needs to be addressed.

Ideally, each delivery problem should be assessed in the round from the site of administration to target cells of interest. And viral vectors probably present a much greater risk of oncogenicity, particularly retroviral vectors that mediate insertion into actively 
expressing gene loci, thereby creating a high risk of oncogenesis (Pfeifer, A. \& Verma, I.M., 2001). This condition must be considered during pharmacokinetic studies.

In short, gene therapy should be seen as a somatic medicine that seeks to treat disease at a more fundamental level than most other therapeutic modalities are capable of. In this field, viral vectors have been extremely attractive as delivery system. An understanding of the pharmacokinetic behavior of these vectors will be utmost important when designing an effective therapeutic regimen, also will provide a comprehensive review of viral vectors and stimulate novel approaches to improve their pharmacokinetics.

\section{Methods used in pharmacokinetic evaluation of viral vectors}

As for pharmacokinetic study of viral vectors in gene therapy, the appropriate methods are of vital importance. With the development of science and technology, there have been many advances in the field of pharmacokinetic study in viral gene therapy. Many approaches have been developed over the past decades, especially in the utilization of molecular strategies for the detection and quantification of viral vectors.

\subsection{Radioactive tracers}

Radioactive tracers are compounds containing one or more radioactive atoms that allow for easy detection and measurement. Tracers are frequently used to track the localization of a specific compound or to trace the path of a compound through a series of chemical reactions. A number of different radioactive forms of hydrogen, carbon, phosphorus, sulfur, and iodine are commonly used in biochemical assays, metabolism studies, and medical diagnostics (Rennie M., 1999).

A radioactive tracer is identical in chemical composition to the compound of interest and is administered in minute amounts that do not perturb the experimental system. The tracer behaves in exactly the same way as an unlabeled molecule, but the tracer molecule continually gives off radiation that can be detected with a Geiger counter, scintillation counter or other type of radiation detection instrument. Zinn K.R. et al. labeled recombinant adenovirus serotype $5 \mathrm{knob}$ with the gamma emitter $99 \mathrm{mTc}$ (Zinn, K.R. et al., 1998). Maarten ter Horst et al. also used ${ }^{99 \mathrm{mTc}}$ to track the distribution of adenoviral vector (Maarten ter Horst et al., 2006). Studies suggest that this technology is sensitive and the radiolabeling process had no effect on receptor binding. However, it is not available in clinic research because the tracers will give off radiation and labs specific for isotope detection are required, which limits its application in research.

\subsection{Polymerase Chain Reaction (PCR)}

The polymerase chain reaction (PCR), developed in 1983 by Kary Mullis, is a scientific technique to amplify a single or a few copies of a piece of DNA across several orders of magnitude, generating thousands to millions of copies of a particular DNA sequence (Bartlett \& Stirling, 2003). It is now a common and usually indispensable technique used in medical and biological research for a variety of applications, including DNA cloning for sequencing, DNA-based phylogeny, functional analysis of genes, identification of genetic fingerprints, and diagnosis of diseases (Saiki, RK. et al., 1988; Glorioso J.C. et al., 1995). A few years ago, the main approach was defining generic biodistribution properties of viral vectors by designing studies often relying on transgene expression and mostly nonvalidated PCR techniques. 
This method has greatly advanced the development of viral gene therapy and progressively helped defining important features of these vectors. But it is just a semi-quantification technology with critical problems, including the number of replicates, the necessity of an internal control, the specificity and the carryover contamination during sample treatment. Besides, the limit of quantification is not as sensitive as expected. In our study, the detection limit of Ad DNA was 10,000 copies per microliter (Figure.1, data unpublished), which greatly hampers the utility of PCR technology in DNA detection when the concentration of DNA in the sample is less than the level mentioned above.

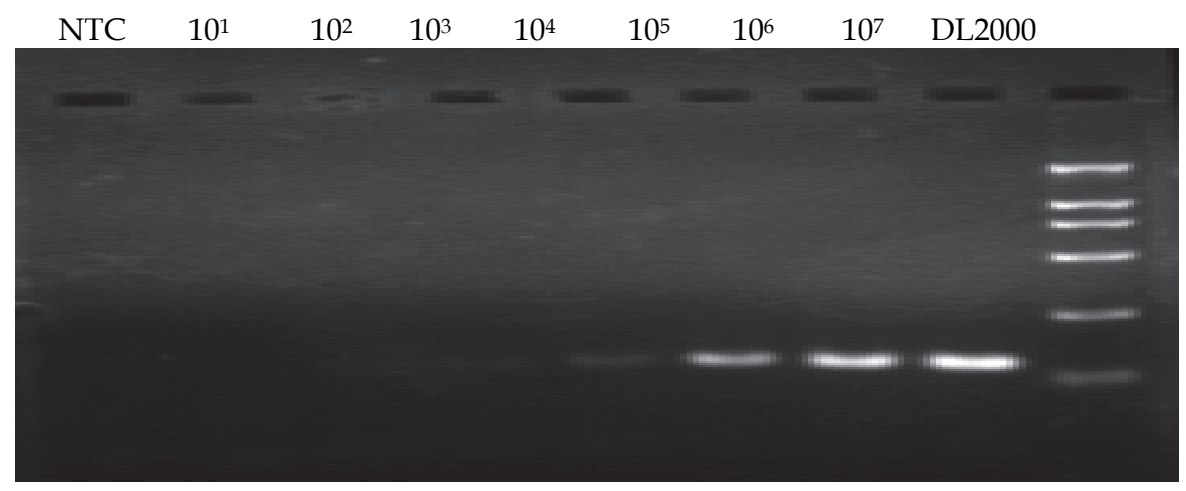

Fig. 1. Validation of the limit of detection of PCR.

Concentrations of DNA in reactions range from $10^{7 \sim 10^{1}}$ copies per microliter.

\subsection{Southern blotting}

Southern blot, developed by Edwin Southern at Edinburgh University in the 1975, allows investigators to determine the molecular weight of a restriction fragment, to measure relative amounts in different samples and to locate a particular DNA sequence within a complex mixture. In this method, DNA (genomic or other source) is digested with a restriction enzyme, separated by gel electrophoresis and transferred from the agarose gel onto a membrane. The membrane is then incubated with a probe, a single-strand DNA labeled either radioactively or enzymatically (e.g. alkaline phosphatase or horseradish peroxidase), which will form a double-strand DNA with its complementary DNA sequence. Finally, the location of the probe is detected by directly exposing the membrane to X-ray film or chemiluminescent methods. Southern blotting had ever played an important role in viral gene therapy. Henderson Y.C. et al developed a method for detecting adenovirus in serum and urine with Southern Blot. Ponnazhagan S. et al used it to evaluate Ad2 in nonpermissive human cells (Ponnazhagan S. et al., 1995). Cichon G et al. and Bernt KM et al. also applied it to investigate gene therapy with adenovirus vectors (Cichon G. et al., 1999; and Bernt K.M. et al., 2003). Those studies suggest its high sensitivity, reproducibility and specificity. However, this method requires a long time and careful manipulation to avoid contamination.

\subsection{Western blot}

Western blot, developed by W. Neal Burnette from the laboratory of George Stark at Stanford, is an effective and useful method to detect and characterize proteins in small 
amounts. In this protocol, gel electrophoresis is used to separate proteins by length of the polypeptide (denaturing conditions) or by the 3-D structure of the protein (native/ nondenaturing conditions). The proteins are then transferred to a membrane (typically nitrocellulose or PVDF), where they are probed using antibodies specific to the target protein. This technique is usually used to evaluate the distribution of vectors by detecting expression of target genes in tissues and demonstrates high specificity and sensitivity, therefore, has been widely used in viral gene therapy. Fanxia Shen et al. applied it to evaluate hypoxia-inducible vascular endothelial growth factor gene expression mediated by adeno-associated viral vector- in mice (Shen FX, et al., 2006).

\subsection{Immunohistochemistry}

Immunohistochemistry (IHC) refers to the process of detecting antigens (e.g., proteins) in cells of a tissue section by exploiting the principle of antibodies binding specifically to antigens in biological tissues (RAMOS-VARA J. A., 2005). ICH staining is widely used in the diagnosis of abnormal cells such as those found in cancerous tumors. Specific molecular markers are characteristic of particular cellular events such as proliferation or cell death (apoptosis). IHC is also widely used in basic research to understand the distribution and localization of biomarkers and differentially expressed proteins in different parts of a biological tissue. Visualising an antibody-antigen interaction can be accomplished in a number of ways. In the most common instance, an antibody is conjugated to an enzyme such as peroxidase that can catalyse a colour-producing reaction. Alternatively, the antibody can also be tagged to a fluorophore, such as fluorescein or rhodamine (Elias J.M., 2003). This method could provide precise information about the distribution of target proteins. However, there are several potential problems that will affect the outcome of the procedure. Although antibodies show preferential avidity for specific epitopes, endogenous biotin or reporter enzymes or primary/secondary antibody cross-reactivity are common causes of strong background staining that can mask the detection of the target antigen, while weak staining may be caused by poor enzyme activity or primary antibody potency. Furthermore, autofluorescence may be due to the nature of the tissue or the fixation method (Grizzle W.E. et al., 2001).

\subsection{Real-time quantitative polymerase chain reaction (Q-PCR)}

The idea to monitor the PCR reaction in the thermal cycler as it progresses was first realized by Higuchi and colleagues in 1992 (Higuchi R. et al., 1992). And the first commercial platform was the Applied Biosystems ABI Prism 7700 Sequence Detection System, followed by the Idaho Technology LightCycler (Wittwer C.T. et al., 1997). The principle of Q-PCR is based on monitoring of a fluorescent signal arising during the amplification process. In this technique two methods are used to obtain fluorescent signals from the PCR products (Fig. 2). One method involves the use of DNA- specific intercalating dyes such as SYBR Green I and the other is to use fluorescent resonance energy transfer (FRET) such as TaqMan ${ }^{\circledR}$ probes (Didenko V.V., 2001).

Q-PCR has revolutionised the detection and quantification of nucleic acid due to its improved rapidity, sensitivity, reproducibility, reduced risk of carry-over contamination, and ability to quantify viral nucleic acid directly from samples (Morris T. et al., 1996; Lovatt A. et al., 1999; Nitsche A. et al., 1999). As a result, real-time PCR assays, as an attractive tool for precise evaluation of nucleic acid, have received wider acceptance than conventional PCR assays in the field of gene therapy. 


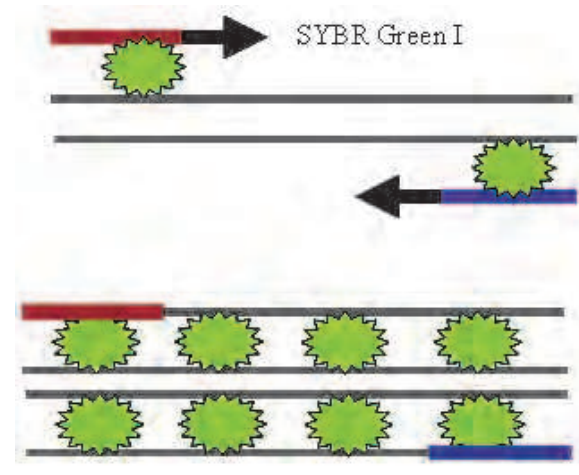

A

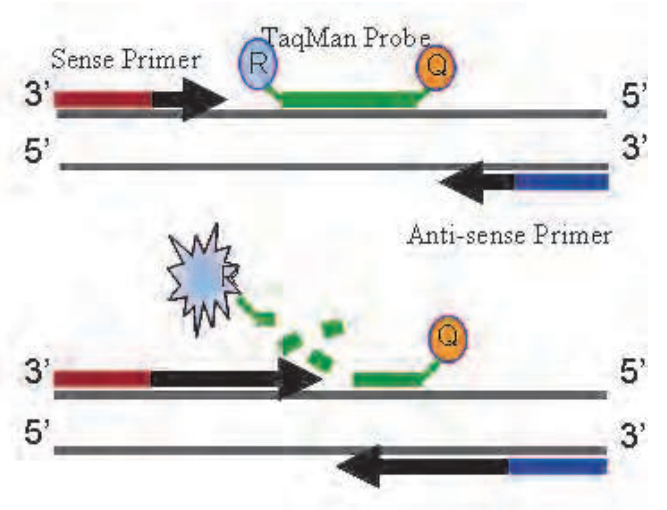

B

Fig. 2. Two methods used to obtain fluorescent signals from the PCR products.

(A) SYBR Green I; (B) TaqMan ${ }^{\circledR}$ probes.

Quantification of viral vectors by a TaqMan real-time PCR assay has been previously reported. Our team employed TaqMan real-time PCR system to investigate the dynamics of Ad5-LFA-3/IgG1 by measuring its concentration in the blood of rhesus macaques and organs of rats (Xu XX et al., 2009). Miyazawa N. et al. examined the kinetics of adenovirus genomic DNA delivery to the nucleus by measuring viral DNA with TaqMan-PCR (Miyazawa N. et al., 1999). Senoo M. et al. assessed the tissue distribution of recombinant adenovirus in mice and guinea pigs via TaqMan-PCR (Senoo M., et al, 2000). Hackett et al. also used TaqMan-PCR to track the time-dependent distribution of vectors in vivo (Hackett N.R. et al, 2000). These studies support the feasibility of utilizing Q-PCR to track viral vectors.

\subsection{In vivo imaging system (IVIS)}

In conventional experimental strategies, temporal information about biological processes is often obtained through repeated, time-stacked animal sacrifice. If fine temporal analysis is sought during the observation of key biological stages in normal development or disease, the number of animals required per experiment can be quite large (Christopher H.C. \& Michael H.B., 2002). Noninvasive imaging methods enable gene expression assays to be conducted in living animals, and they comprise the emerging field of in vivo imaging in which a variety of imaging modalities are used for real-time visual monitoring and assessment of biological processes in living animals (Ntziachristos V., 2006). As shown in Fig.3, this technology greatly reduces the number of animals sacrificed per experiment because they allow the comprehensive assessment of each animal over the entire duration of the process (Contag P.R. et al., 1998; Rocchetta H.L. et al., 2001).

Despite obvious progress in gene therapy, the recent failure of trials using adenoviral vectors reminds us that the use of viral vectors has risks that should be carefully assessed. What's more, great the progress in viral vector production, and a better understanding of molecular aspects of vector delivery and targeting issues, has created the need for imaging techniques that could address the problems and opportunities inherent to gene therapy development. As noted previously, in vivo imaging could play a unique role in preclinical and clinical 


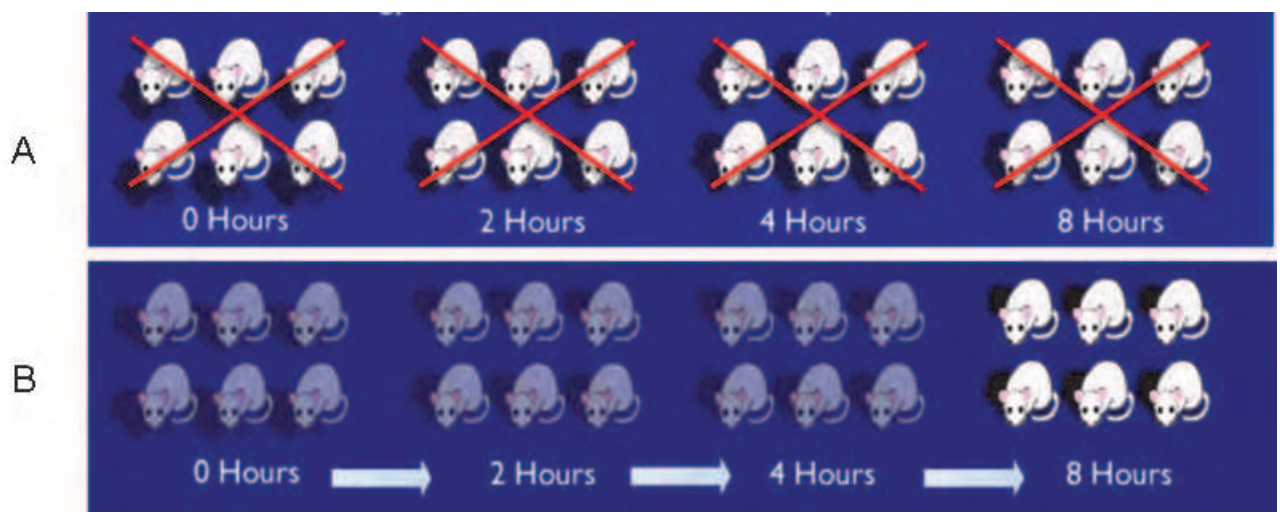

Fig. 3. Comparison of conventional experimental strategies and Noninvasive imaging methods. (A) conventional experimental strategies; (B) Noninvasive imaging methods

gene therapy research and answer the following fundamental questions asked by gene therapists:

- How long would the vector reach its target after in vivo administration?

- How many of the vectors are in the target?

- When the expression would take place?

- How long would the expression last?

- Did gene transfer take place?

There have been many recent advances in imaging research to provide answers to these questions mentioned above, and particularly in the utilization of such strategies for the distribution studies of viral vectors. The imaging technology alone, however, can only yield limited information, and pharmacokinetics parameters remain unclear. In this regard, more efforts are required to develop multi-modality imaging strategies allowing for coregistration of high resolution anatomical data together with high sensitive molecular information.

\section{Challenges and prospects}

As noted previously, viral gene therapy research has evolved considerably since the first clinical trials of this technology. The range of therapeutic targets has also expanded from the treatment of monogenetic disorders to the prevention and treatment of acquired diseases, and so has the number and range of possible therapeutic nucleic acids. This therapeutic modality represents one of the most important developments to occur in medicine. On the other hand, certain technical problems arising from pharmacokinetic studies of viral gene therapy remain to be overcome.

Design and development of ideal gene delivery vectors (Table. 2) are among the main challenges in the evolution of experimental gene therapy into a clinically acceptable mainstream therapy (Rubanyi, G.M., 2001). In spite of the relatively undemanding nature of the selected viral vectors in clinical trials, results from many early stage clinical trials have been frequently disappointing due to the inadequacy of the vectors. The main hurdle for successful viral gene therapy has been the host response to the gene therapy vector, the lack 
of long-term gene expression, and problems related to the viral property of integration (Neeltje A. K. \& Inder M. V. 2003), all of which represent the general aim of pharmacokinetic studies in viral gene therapies. Together, the choice of vector, the design of the expression cassette, and the coding sequence of the genes determine the pharmacokinetics of vectors. Additionally, innovations in vector design will require a better understanding of delivery problems, both at the level of intracellular trafficking of viral DNA to the nucleus and at the level of biological fluid stability and tissue penetration. Hence, much more basic research is needed to interpret the mechanism of viral gene therapy.

\begin{tabular}{cc}
\hline $\begin{array}{c}\text { Insert size } \\
\text { Targeting } \\
\text { Regulation }\end{array}$ & $\begin{array}{c}\text { capacity for one or more genes } \\
\text { delivery to specific cell types or gene } \\
\text { expression limited to target cells }\end{array}$ \\
$\begin{array}{c}\text { Safety and stability } \\
\text { controllable expression levels of transgenes } \\
\text { Immune response } \\
\text { Titles }\end{array}$ & $\begin{array}{c}\text { of the risk of insertional mutagenesis } \\
\text { appropriate }\end{array}$ \\
Manufacture & easy, reproducible, possible for scale-up and standardization \\
\hline
\end{tabular}

Table 2. The ideal vector for gene transfer in gene therapy protocols (Dani, S.U., 1999).

Over the past decades, the process and validation of bioanalytical methods have been well developed to generate pharmacokinetic data and provide ADME (absorption, distribution, metabolism, and elimination) information on biotech drugs. However, pharmacokinetic principles of viral gene therapy are far away from sufficiency in spite of long-term and extensive efforts, which requires more considerations when developing bioanalytical approaches in gene therapy with viral vectors, including validation and assay implementation.

Despite recent advances in analytical techniques, further improvements in current analysis modalities are still at the center stage. As mentioned above, all of the technologies mentioned in the review have played important roles during the development of viral gene therapy and provided us important information. But only limited material can be obtained when these methods are used alone.

Challenges including pharmacokinetic studies and analytical methods were shortly described above. It is evident that overcoming these barriers will contribute greatly to the development of viral gene therapy.

In recent years, more attention has been paid on new viral vectors and modifying the existing ones to make them have less toxicity and immunity, besides, with ideal pharmacokinetic features. A number of strategies have evolved to enhance the targeting of gene transfer vectors by genetic or chemical modification on the surface of the vector. Gene expression directed by the transferred gene can be regulated by inducible promoters, tissuespecific promoters, and trans-splicing. And many hybird or chinmeric vectors have emerged. Mizuguchi H. et al. developed adenovirus vectors containing chimeric type 5 and type 35 fiber proteins, which exhibit altered and expanded tropism and increase the size limit of foreign genes (Mizuguchi H. \& Hayakawa T., 2002). Lars Mullera et al. developed hybrid vectors HSV-EBV (hepies-simplex-virus-epstein-barrvirus hybrid amplicons) to transfer genes into hepatocytes (Mullera L. et al., 2005). Goncalves MA et al. developed 
AAV-Ad hybrid vectors, improving the transfer efficiency and expression duration (Goncalves M.A. et al., 2002). These approaches will, consequently, provide more vectors practicable in clinical gene therapies.

Besides, on the basis of what mentioned above, no single modality is ideal for all possible applications and, thus, new protocols for pharmacokinetic studies have been developed in viral gene therapy. Wood M. et al. investigated the biodistribution of Ad vector following systemic administration with a PCR and luciferase assay (Mark Wood et al., 1999), which provided semi-quantitative and qualitative analyses of vector distribution. Pan D. et al. applied real-time PCR method and flow-cytometric analysis to measure the distribution of lentiviral Vector and expression of target gene in various organs (Dao Pan et al., 2002). And our team used TaqMan real-time PCR and in vivo imaging system to track the timedependent distribution of rAd5/35 in vivo post intramuscular injection. The vector was found to remain primarily at the injection site for about eight weeks, at which point it became undetectable (Fig. 4). This result was also shown by in vivo imaging of rAd5/35-luc in Balb/c mice (Fig. 5). What's more, as shown in Fig. 6, the whole process of luciferase expression could be monitored in Balb/c mice post-injection with rAd5/35-luc. Quantitative and qualitative results could be attained through the utility of real-time PCR and IVIS technology in biodistribution study of viral gene therapy. In general, the combination of these two approaches provides a rapid, simple approach for a precise, visible result and will ultimately accelerate the progress of gene therapy studies.

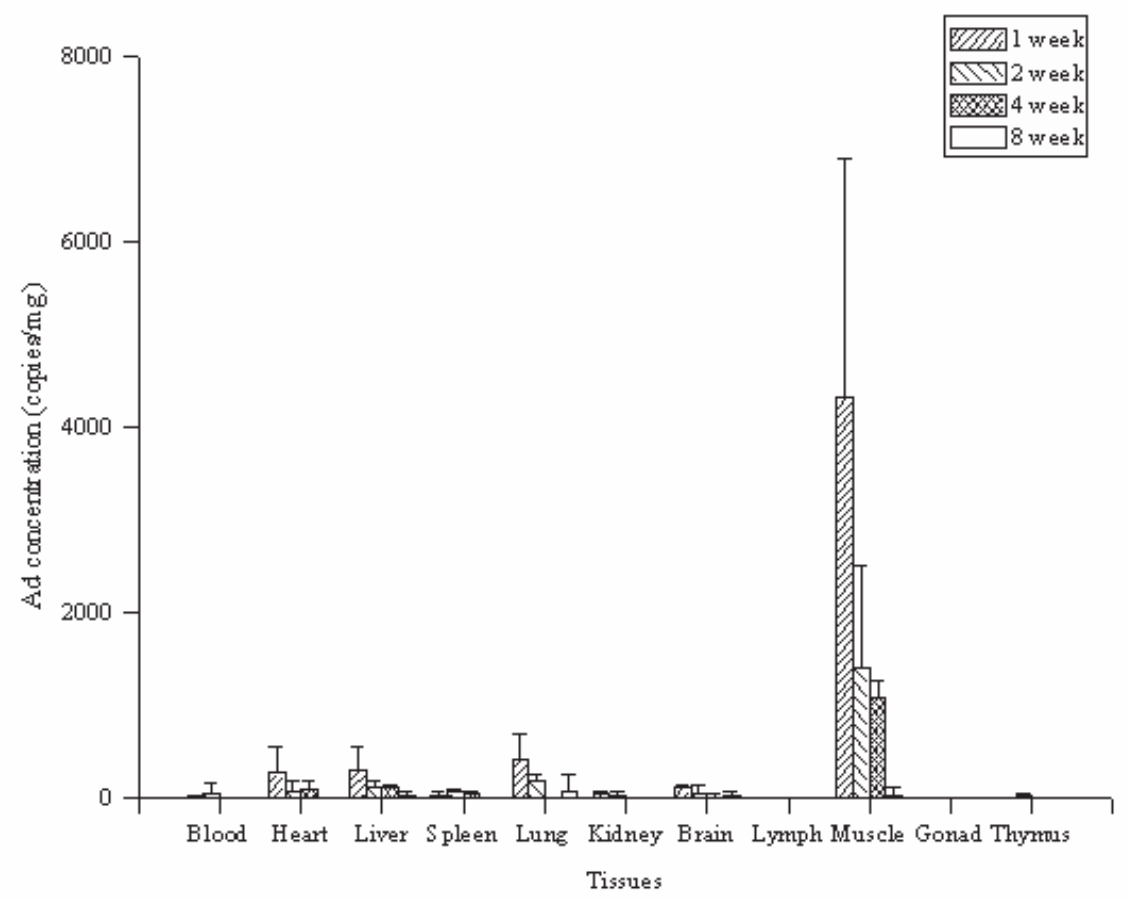

Fig. 4. Biodistribution of rAd5/35-HGEC in tissues of Balb/c mice post-injection with $1.6 \times 10^{9} \mathrm{vp}$ 


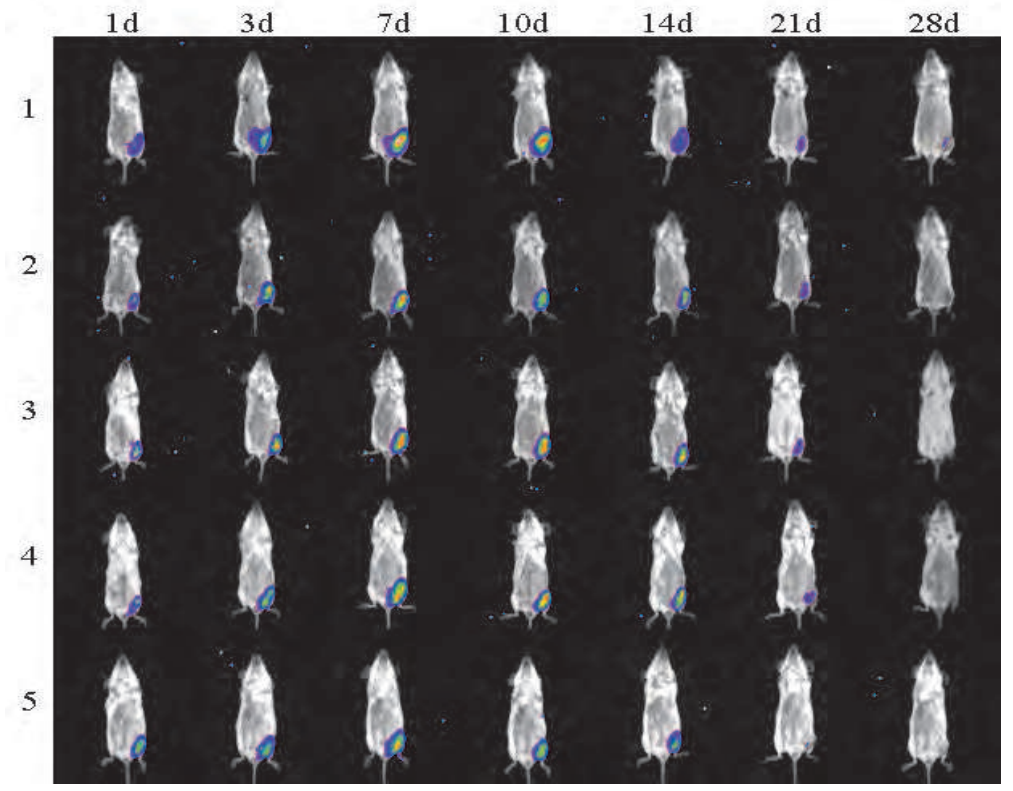

Fig. 5. Luciferase expression in Balb/c mice post-injection with $\mathrm{rAd} 5 / 35-\mathrm{luc}$ $\left(2 \times 10^{10} \mathrm{vp}\right) \quad(\mathrm{n}=5)$

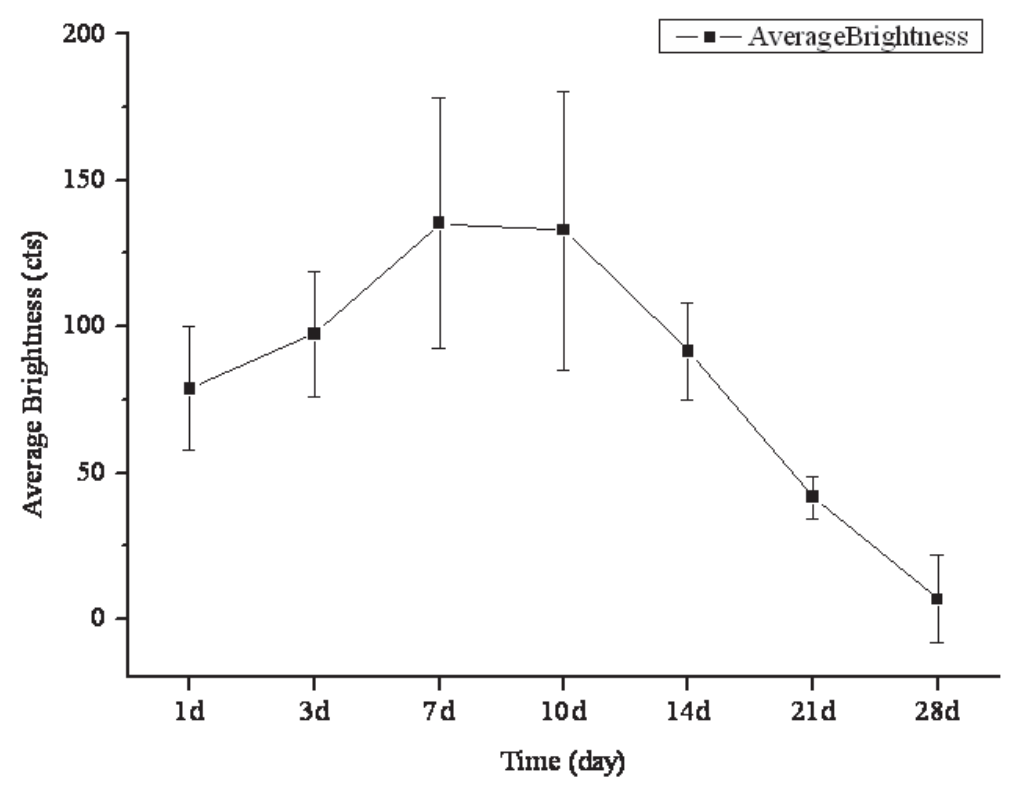

Fig. 6. Duration of luciferase expression in Balb/c mice post-injection with rAd5/35-luc $\left(2 \times 10^{10} \mathrm{vp}\right)(\mathrm{n}=5)$. 
The young field of viral gene therapy promises major medical progress toward the cure of a broad spectrum of human diseases, and has generated great hopes. To achieve this goal, scientists from many different disciplines should participate and pull together as a team. Geneticists must identify target genes while the task for the virologists is to develop efficient and safe vectors. Finally, clinicians carry out clinical trials with vectors optimized for the disease and the medical requirements of the patients (Pfeifer, A. \& Verma, I.M., 2001).

On the whole, progress has been made in addressing many of these challenges over the past decades. Based on the continued focus on solving these issues, the knowledge gained from the successes and the setbacks will prove beneficial in viral gene therapy, and there is no doubt that prodigious work will result in innovative technology for pharmacokinetic studies.

\section{Conclusion}

Gene therapy with viral vectors has been proven very effective in a variety of model systems. And great progress has been made in pharmacokinetic studies of viral gene therapy. However, there are still many challenges, including the host response to the viral vectors, the lack of long-term gene expression, and the risks related to integration into the host genome. Thus, understanding of the pharmacokinetic behavior of viral vectors and developing ideal methods for pharmacokinetic studies will greatly accelerate the development of gene therapy. It's believed that gene therapy has the power to become a dominant therapeutic modality in the future - but all in good time.

\section{References}

Pfeifer, A. \& Verma, I.M., (2001) Gene Therapy: Promises and Problems. Annual Review of Genomics and Human Genetics. 2: 177-211.

Arruda VR, Fields PA, Milner R, Wainwright L, De Miguel MP, Donovan PJ, Herzog RW, Nichols TC, Biegel JA, Razavi M, Dake M, Huff D, Flake AW, Couto L, Kay MA \& High KA. (2001) Lack of germline transmission of vector sequences following systemic administration of recombinant AAV-2 vector in males. Molecular Therapy. 4: 586-592.

Lovatt A. (2002) Applications of quantitative PCR in the biosafety and genetic stability assessment of biotechnology products. Reviews in Molecular Biotechnology. 82: 279-300

Bartlett \& Stirling, (2003) A Short History of the Polymerase Chain Reaction. In: Methods Mol Biol. 226:3-6.

Meibohm, B. (2006) The role of Pharmacokinetics and Pharmacodynamics in the Development of Biotech Drugs, In: Pharmacokinetics and Pharmacodynamics of Biotech Drugs: Principles and case studies, Bernd Meibohm, pp, 3-13, WILEY-VCH Verlag GambH \& Co. KGaA, ISBN-13: 978-3-527-31408-9, Germany.

Bernt, K.M., Ni, S., Li, Z.L., Shayakhmetov D.M. \& Lieber A. (2003) The effect of sequestration by nontarget tissues on anti-tumor efficacy of systemically applied, conditionally replicating adenovirus vectors. Molecular Therapy. 8: 746-755. 
Cichon G., Hartmut H. Schmidt, Tahar Benhidjeb, Peter Löser, Sabine Ziemer, Regina Haas, Nicole Grewe, Frank Schnieders, Jörg Heeren, Michael P. Manns, Peter M. Schlag \& Michael Strauss. (1999) Intravenous administration of recombinant adenoviruses causes thrombocytopenia, anemia and erythroblastosis in rabbits. Journal of Gene Medicine. 1: 360-371.

Cavazzana-Calvo, M., Hacein-Bey, S., de Saint Basile, G., Gross, F., Yvon, E., Nusbaum, P., Selz, F.; Hue, C., Certain, S., \& Casanova, J. L., (2000). Gene therapy of human severe combined immunodeficiency (SCID)-X1 disease[J]. Science, 288(5466): 669 672

Cavazzana-Calvo, M., Thrasher, A., \& Mavilio, F. (2004) The future of gene therapy. Nature. 427: 779-781.

Christopher H. Contag \& Michael H. Bachmann. (2002) Advances In In Vivo Bioluminescence Imaging Of Gene Expression. Annu. Rev. Biomed. Eng. 4:235-260.

Contag PR, Olomu IN, Stevenson DK \& Contag CH. 1998. Bioluminescent indicators in living mammals. Nat. Med. 4:245-247.

Pan D., Gunther R., Duan W., Wendell S., Kaemmerer W., Kafri T., Verma I.M. \& Whitley C.B. (2002) Biodistribution and Toxicity Studies of VSVG-Pseudotyped Lentiviral Vector after Intravenous Administration in Mice with the Observation of in Vivo Transduction of Bone Marrow. Melocular Therapy, 6: 19-29.

Dani, S.U., (1999) The challenge of vector development in gene therapy. Brazilian Journal of Med ical and Biological Research. 32: 133-214.

Didenko, V.V., (2001) DNA probes using fluorescence resonance energy transfer (FRET): designs and applications. Biotechniques .31: 1106-1121.

Elias JM (2003) Immunohistochemical methods. In: Immunohistopathology. A Practical Approach to Diagnosis, ed. Elias JM, 2nd ed., pp. 1-110. ASCP Press, Chicago, IL.

Shen FX, Su H, Fan Y, Chen Y, Zhu Y, Liu W, Young WL \& Yang GY. (2006) AdenoAssociated Viral Vector-Mediated Hypoxia-Inducible Vascular Endothelial Growth Factor Gene Expression Attenuates Ischemic Brain Injury After Focal Cerebral Ischemia in Mice. Stroke, 37: 2601-2606

Gaspar, H. B., \& Thrasher, A. J. (2005) Expert Opinion on Biological Therapy. 5: 11751182.

Glorioso JC, DeLuca NA \& Fink DJ. (1995) Development and application of herpes simplex virus vectors for human gene therapy. Annu Rev Microbiol. 49:675-710.

Gonçalves MA, van der Velde I, Janssen JM, Maassen BT, Heemskerk EH, Opstelten DJ, Knaän-Shanzer S, Valerio D \& de Vries AA. (2002) Efficient gene ration and amplification of high - capacity adeno - associated virus Padenovirus hybrid vectors. Journal of Virology. 76(21):10734 - 10744.

Grizzle WE, Stockard CR, Billings PE. (2001) The effects of tissue processing variables other than fixation on histochemical staining and immunohistochemical detection of antigens. J Histotechnol. 24: 213-219.

Hackett, N. R., El Sawy, T., Lee, L. Y., Silva, I., O'Leary, J., Rosengart, T. K., Crystal R.G., (2000) Use of quantitative TaqMan Real-Time PCR to track the time-dependent distribution of gene transfer vectors in vivo. Molecular Therapy, 2: 649-656. 
Henderson Y.C., Liu T.J., Clayman G.L., (1998) A simple and sensitive method for detecting adenovirus in serum and urine. Journal of Virological Methods. 71: 51-56.

Higuchi, R., Dollinger, G., Walsh, P.S. \& Griffith, R., (1992) Simultaneous amplification and detection of specific DNA sequences. Biotechnology (NY). 10: 413-417.

Mizuguchi H. \& Hayakawa T. (2002)Adenovirus vectors containing chimeric type 5 and type 35 fiber proteins exhibit altered and expanded tropism and increase the size limit of foreign genes. Gene. 285:69-77.

Kok, T., Wati, S., Bayly, B., Devonshire-Gill, D. \& Higgins, G., (2000) Comparison of six nucleic acid extraction methods for the detection of viral DNA or RNA sequences in four different non-serum specimen types. Journal of Clinical Virology. 16: 59-63.

Lovatt A, Black J, Galbraith D, Doherty I, Moran MW, Shepherd AJ, Griffen A, Bailey A, Wilson N\& Smith KT. (1999) High throughput detection of retrovirus- associated reverse transcriptase using an improved Fluorescent Product Enhanced Reverse Transcriptase Assay( F-PERT) and its comparison to conventional detection methods. Journal of Virology Methods. 82: 185-200.

ter Horst M., Verwijnen S.M., Brouwer E, Hoeben R.C., de Jong M., de Leeuw B.H., Sillevis Smitt P.A. (2006) Locoregional Delivery of Adenoviral Vectors. Journal of Nuclear Medicine. 47: 1483-1489

Marshall, E. (2000) Gene Therapy on Trial. Science. 288 (5468): 951-957.

Wood M., Perrotte P., Onishi E., Harper M.E., Dinney C., Pagliaro L. \& Wilson D.R. (1999) Biodistribution of an adenoviral vector carrying the luciferase reporter gene following intravesical or intravenous administration to a mouse. Cancer Gene Therapy.6: 367-372.

MacLachlan, I., Cullis, P., \& Graham, R. W., (1999) Curr. Opin. Molecular Therapy. 1: 252259.

Miyazawa, N., Leopold, P. L., Hackett, N. R., Ferris, B., Worgall, S. \& Falck-Pedersen, E., (1999) Fiber swap between adenovirus subgroups B and C alters intracellular trafficking of adenovirus gene transfer vectors. Journal of Virology, 73: 60566065.

Morris, T., Robertson, B. \& Gallagher, M., 1996. Rapid reverse transcription-PCR detection of hepatitis $C$ virus RNA in serum using TaqMan fluorogenic detection system. Journal of Clinical Microbiology. 34: 2933-2936.

Müller L, Saydam O, Saeki Y, Heid I \& Fraefel C. (2005) Gene transfer into hepatocytes mediated by hepies simplex-virus-epstein-barrvirus hybrid amplicons. Journal of Virological Methods. 123: 65- 72.

Kootstra N.A. \& Verma I.M. (2003) Gene Therapy With Viral Vector. Annu. Rev. Pharmacol. Toxicol. 43: 413-439.

Hackett N.R., Sawy T.E., Lee L.Y., Silva I., O'Leary J., Rosengart T.K. \& Crystal R.G. (2000) Use of Quantitative TaqMan Real-Time PCR to Track the Time-Dependent Distribution of Gene Transfer Vectors in Vivo. Molecular Therapy. 2: 649-656. 
Nitsche, A., Steuer, N., Schmidt, C.A., Landt, O. \& Siegert, W., (1999) Different real-time PCR formats compared for the quantitative detection of human cytomegalovirus DNA. Clinical Chemistry. 45: 1932-1937.

Perlman, J., Gibson, C., Pounds, S.B., Gub, Z., Bankowski, M.J., \& Haydenb, R.T. (2007) Quantitative real-time PCR detection of adenovirus in clinical blood specimens: A comparison of plasma, whole blood and peripheral blood mononuclear cells. Journal of Clinical Virology. 40: 295-300.

Pearson, S., Jia H \& Kandachi, K., (2004) China approves first gene therapy[J]. Nature Biotechnology, 22(1): 3 4.

Ponnazhagan S., Woody M.J., Wang XS, Zhou SZ \& Srivastava A. (1995) Transcriptional transactivation of parvovirus B19 promoters in nonpermissive human cells by adenovirus type 2. Journal of Virology. 69: 8096-8101.

RAMOS-VARA J. A. (2005) Technical Aspects of Immunohistochemistry. Vet Pathol. 42:405-426.

Rennie M., (1999) An introduction to the use of tracers in nutrition and metabolism . Proceedings of the Nutrition Society. 58 (4): 935-944.

Rocchetta HL, Boylan CJ, Foley JW, Iversen PW, LeTourneau DL, McMillian CL, Contag PR, Jenkins DE \& Parr TR Jr. (2001) Validation of a noninvasive, real-time imaging technology using bioluminescent Escherichia coli in the neutropenic mouse thigh model of infection. Antimicrob. Agents Chemother. 45:129-137

Rubanyi, G.M. (2001) The future of human gene therapy. Mol.Aspects Med. 22, 113142.

Saiki, RK; Gelfand DH, Stoffel S, Scharf SJ, Higuchi R, Horn GT, Mullis KB \& Erlich HA (1988). Primer-directed enzymatic amplification of DNA with a thermostable DNA polymerase. Science. 239 (4839): 487-491.

Senoo, M., Matsubara, Y., Fujii, K., Nagasaki, Y., Hiratsuka, M. \& Kure, S., (2000). Adenovirus-mediated in utero gene transfer in mice and guinea pigs: Tissue distribution of recombinant adenovirus determined by quantitative TaqMan-polymerase chain reaction assay. Molecular Genetics and Metabolism. 69: 269-276.

Worgall S. \& Crystal R.G. (2007) Gene Therapy, In: Principles of Tissue Engineering, 3rd Edition, ed. by Lanza, Langer, and Vacanti, Copyright (C) 2007, Elsevier, Inc.

Thanou, M., Waddington, S., \& Miller, A D., (2007) Gene Therapy. Comprehensive Medicinal Chemistry II, 297-319, Elsevier Ltd. ISBN (set): 0-08-044513-6, ISBN (Volume 1) 0-08-044514-4, USA.

Ntziachristos V. (2006) Fluorescence Molecular Imaging. Annual Review of Biomedical Engineering. 8:1-33.

Wittwer, C.T., Ririe, K.M., Andrew, R.V., David, D.A., Gundry, R.A. \& Balis, U.J. (1997) The LightCycler: a microvolume multisample fluorimeter with rapid temperature control. Biotechniques. 22: 176-181.

Xu XX, Shui X, Chen ZH, Shan CQ, Hou YN \& Cheng YG (2009) Development and Application of a Real-time PCR Method for Pharmacokinetic and Biodistribution Studies of Recombinant Adenovirus. Molecular Biotechnology. 43:130-137. 
Zinn KR, Douglas JT, Smyth CA, Liu HG, Wu Q, Krasnykh VN, Mountz JD, Curiel DT \& Mountz JM. (1998) Imaging and tissue biodistribution of 99mTc-labeled adenovirus knob (serotype 5). Gene Therapy. 5: 798-808. 


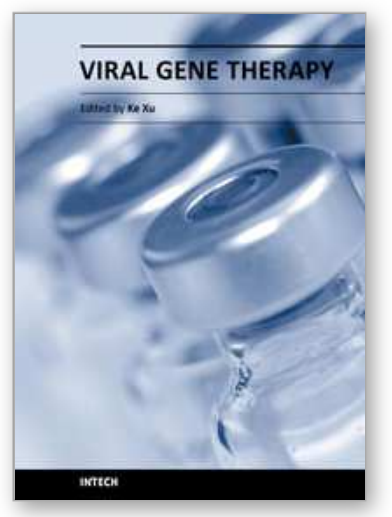

\author{
Viral Gene Therapy \\ Edited by Dr. Ke Xu
}

ISBN 978-953-307-539-6

Hard cover, 450 pages

Publisher InTech

Published online 20, July, 2011

Published in print edition July, 2011

The development of technologies that allow targeting of specific cells has progressed substantially in recent years for several types of vectors, particularly viral vectors, which have been used in $70 \%$ of gene therapy clinical trials. Particular viruses have been selected as gene delivery vehicles because of their capacities to carry foreign genes and their ability to efficiently deliver these genes associated with efficient gene expression. This book is designed to present the most recent advances in viral gene therapy

\title{
How to reference
}

In order to correctly reference this scholarly work, feel free to copy and paste the following:

Xianxing Xu, Yang Jingwen and Cheng Yuanguo (2011). Pharmacokinetic Study of Viral Vectors for Gene Therapy: Progress and Challenges, Viral Gene Therapy, Dr. Ke Xu (Ed.), ISBN: 978-953-307-539-6, InTech, Available from: http://www.intechopen.com/books/viral-gene-therapy/pharmacokinetic-study-of-viral-vectorsfor-gene-therapy-progress-and-challenges

\section{INTECH}

open science | open minds

\section{InTech Europe}

University Campus STeP Ri

Slavka Krautzeka 83/A

51000 Rijeka, Croatia

Phone: +385 (51) 770447

Fax: +385 (51) 686166

www.intechopen.com

\section{InTech China}

Unit 405, Office Block, Hotel Equatorial Shanghai

No.65, Yan An Road (West), Shanghai, 200040, China

中国上海市延安西路65号上海国际贵都大饭店办公楼 405 单元

Phone: +86-21-62489820

Fax: $+86-21-62489821$ 
(C) 2011 The Author(s). Licensee IntechOpen. This chapter is distributed under the terms of the Creative Commons Attribution-NonCommercialShareAlike-3.0 License, which permits use, distribution and reproduction for non-commercial purposes, provided the original is properly cited and derivative works building on this content are distributed under the same license. 